\title{
Analysis of interrelations between wheat protein fractions composition and its technological quality by combined multivariate and univariate statistics
}

\author{
Jasna S. Mastilović ${ }^{1}$, Daniela I. Horvat ${ }^{2}$, Dragan R. Živančev ${ }^{1}$, Aleksandra M. Torbica ${ }^{1}$, Žarko S. Kevrešan ${ }^{1}$, \\ Nevena Đukić ${ }^{3}$, Damir N. Magdić, ${ }^{4}$, Gordana H. Šimić \\ ${ }^{1}$ University of Novi Sad, Institute of Food Technology, Bulevar cara Lazara 1, 21000 Novi Sad, Serbia \\ ${ }^{2}$ Agricultural Institute Osijek, Južno predgrađe 17, 31000 Osijek, Croatia \\ ${ }^{3}$ University of Kragujevac, Faculty of Natural Science, Radoja Domanovića 12, 34000 Kragujevac, Serbia \\ ${ }^{4}$ University J.J. Strossmayer, Faculty of Food Technology Osijek, Franje Kuhača 18, 31000 Osijek, Croatia
}

\begin{abstract}
Data on protein fractions' proportion, obtained with RP-HPLC and technological quality parameters for 29 wheat cultivars grown in Serbia and Croatia, were used for studying of interrelations among wheat protein fractions with different solubility and molecular weight properties by multivariate (PCA) analysis. Obtained trends were used as the base for investigations related to differentiation of technological quality among wheat cultivars with different combination of protein fractions' compositions using univariate statistics (ANOVA followed by Duncan's test) in order to draw out information about interrelations between protein fractions proportion in wheat cultivars and their technological quality. Analysis based on the first four PCA factors (89.04\% of variability) pointed out interdependencies between: 1) high content of albumins and globulins, low gliadins content and gliadins/glutenins ratio, high $\omega$-gliadins, LMW glutenins and low $\alpha$-gliadins share in total protein with low water absorption, high energy and high resistance to extensibility ratio, 2) high albumin and globulin content and high proportion of $\omega$-gliadins in total protein and low extensigraph extensibility, 3) high share of high molecular weight glutenins (HMW-GS) in total proteins, high extensigraph resistance/extensibility ratio and 4) high $\gamma$ gliadins share in total protein and low extensigraph resistance/extensibility ratio.
\end{abstract}

Keywords: wheat, genotype, quality properties, albumins and globulins, gluten proteins, RP-HPLC.

\author{
SCIENTIFIC PAPER \\ UDC 633.11:631.52:575:543.544 \\ Hem. Ind. 68 (3) 321-329 (2014) \\ doi: 10.2298/HEMIND130313057M
}

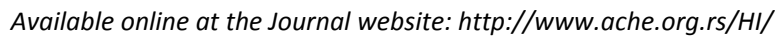

The content and composition of wheat protein are considered to be among the major factors that influence on the technological properties and quality of final products of wheat processing [1,2].

The influence of wheat protein fractions on dough rheological properties and end use quality of wheat has been the subject of numerous studies that included the use of sodium dodecil sulphate polyacrilamid gel electrophoresis (SDS-PAGE) [3-5], capillary electrophoresis [6], electrophoresis on chip [7] or high performance liquid chromatography (HPLC) [4,8-11] for fractioning of wheat proteins by their molecular weights.

The gluten content has proven to be positively correlated with some of the properties of wheat technological quality, such as farinographs dough development and stability [12], and water absorptions and dough development time, whereas the negative corre-

Correspondence: J.S. Mastilović, University of Novi Sad, Institute of Food Technology, Bulevar cara Lazara 1, 21000 Novi Sad, Serbia.

E-mail: jasna.mastilovic@fins.uns.ac.rs

Paper received: 13 March, 2013

Paper accepted: 24 April, 2013 lation is confirmed with extensigraphs resistance and resistance, and extensibility ratio [1]. The properties of gluten are also influencing the parameters used for evaluation of dough rheological properties. The partial explanation and prediction of some dough rheological properties, like extensigraph energy, can be obtained from results of rapid methods like gluten index [1], which are depending on gluten molecular structure or even better by modification of gluten index procedure which includes also the enzymatic activity that has influence on gluten composition [13].

The quantity and ratio of two main gluten fractions, glutenin and gliadin, have also notable influence on dough properties and bread making quality [14]. It is well known that glutenins are responsible for dough elasticity, whereas gliadins are more viscous and influence mainly on dough extensibility [15]. According to Torbica et al. [13] increase of gliadin and glutenin ratio explained the drop of extensigraph energy.

The glutenins are, based on electrophoretic mobility, recognized as high molecular weight glutenins (HMW-GS) with molecular weight from 80000 to 
130000 [16] and low molecular weight glutenins (LMWGS) with molecular weight from 30000 to 50000 [17].

HMW-GS composition depends on origin from specific genome and it is accepted to be one of the most important genetic factors determining empirical properties of dough [18]. Therefore, numerous research results were reported which connect influence of composition of HMW-GS with technological quality of wheat $[4,5,9,19]$, but almost all reported studies HMW-GS are interpreted based on genetic alleles structure and are not divided by different molecular weights. The approach of analysis of influence of presence and quantity of glutenin fractions with different molecular weights on wheat technological quality was recently reported by Živančev et al. [7].

Regarding the influence of LMW-GS on dough rheological properties it was reported by Luo et al. [3] that they play important role in determining dough extensibility, while role in determining dough strength is less important and is related to HMW-GS.

In academic literature, the gliadins are divided according electrophoretic mobility in acid conditions into $\alpha-, b-, \gamma$ - and $\omega$-classes [20]. Thomson et al. [21] found that molecular weight of $\alpha, \gamma$ and $\omega$ gliadins are approximately 35000, 45000 and 58000, respectively, using the small angle X-ray scattering. In the past, the relative contribution of specific composition of gliadin subunits in determining of wheat dough properties was not quite clear [22], except in the case of some subunits of $\omega$-gliadins which were reported to affect the dough extensibility [23]. The recent study by Wang et al. [24] confirmed that others subunits of $\omega$-gliadins could influence on dough strength, whereas Gobaa et al. [25] showed that high amount of $\alpha$-gliadins has improved dough extensibility. However, Gil-Humanes et al. [26] in their research did not confirm the important role of $y$-gliadins on dough rheology.

The albumins and globulins, fractions of wheat proteins soluble in water and salt solution, represent only several wheat endogenous enzymes [27] and enzyme inhibitors [28]. Their effect on dough properties and their role on dough strength and baking properties are not thoroughly investigated $[29,30]$.

The basic statistic including analysis of correlations between pairs of variables was mainly used in the above-mentioned research about dependence between protein fractions and dough rheological properties. The utilization of multivariate statistics for explanation of interdependencies should be considered, having in mind that wheat dough is complex matrix in which all components interact resulting in final rheological properties, which was not found in reported research in this field [31].

In this study the interrelations among wheat protein fractions with different solubility and molecular weight properties are going to be studied for cultivars grown in south of Pannonian Plain by multivariate analysis. The obtained trends will further be used as the base for investigations related to differentiation of individual technological quality parameters among wheat cultivars with different combination of protein fractions proportion in order to draw out information about interrelations between protein fractions proportion in wheat cultivars and their technological quality.

\section{EXPERIMENTAL}

The examinations have been carried out on 16 bread wheat cultivars (Srpanjka, Žitarka, Divana, Aida, Felix, Zlata, Ilirija, Ružica, Sana, Seka, Renata, Golubica, Soissons, Olimpija, Vulkan and Tihana) grown in Croatia at the Agricultural Institute Osijek and 16 bread cultivars grown in Serbia (Vojvodina, Angelina, Dragana, Ljiljana, NS rana 5, Pobeda, Bastijana, Evropa 90, NS 40S, Simonida, Kantata, Etida, Renesansa, Zvezdana, Rapsodija and NS3-5299/2) at the Institute of Field and Vegetable Crops, Novi Sad, in 2009.

The protein content of wheat kernels was measured by Infratec 1241 (Foss Tecator, Höganäs, Sweden), the Falling Number was determined by ICC method No $107 / 1$ [32], whereas wet gluten and gluten index of flour samples were determined according to ICC method No. 155 [33]. The dough rheology was measured by the Brabender (C.W. Brabender, Duisburg, Germany) equipments farinograph and extensigraph (ICC methods No. 115/1 [34] and 114/1 [35], respectively).

The procedure for extraction of wheat proteins and RP-HPLC method were performed according to Wieser et al. [36]. Perkin Elmer LC 200 chromatograph (Perkin Elmer Instruments, Waltham, USA) was utilized with a Supelco Discovery Bio Wide Pore C18 column (300 pore size, $5 \mu \mathrm{m}$ particle size, $4.6 \mathrm{~mm} \times 250 \mathrm{~mm}$ i.d.) purchased from Sigma-Aldrich, Steinheim, Germany. Solvents were consisted of water and acetonitrile (ACN), comprised of $0.1 \%(\mathrm{~V} / \mathrm{V})$ trifluoroacetic acid (TFA). 20 $\mu \mathrm{L}$ samples were injected for analyses. Wheat protein fractions were eluted with a linear gradient from 24 to $58 \% \mathrm{ACN}$ over $30 \mathrm{~min}$ at $1 \mathrm{~mL} / \mathrm{min}$, using a column temperature of $50{ }^{\circ} \mathrm{C}$. All samples were scanned by UV absorbance at $210 \mathrm{~nm}$ in duplicate. The gained chromatograms were examined by Total-Chrom software package (Perkin Elmer Instruments, Waltham, USA). The peak areas (expressed in arbitrary units, AU) under albumins-globulins, gliadins and glutenins chromatograms were totalized and used as a direct extent of total wheat proteins content. Furthermore, the share of all protein fractions in total extracted wheat proteins was calculated.

The data were statistically analyzed by Statistica 10.0 (StatSoft Inc., USA) software [37]. Principal component analysis (PCA) was used to investigate associations among wheat protein fractions. Further on, 
ANOVA was used for testing of differentiation of quality parameters among cultivars for which PCA indicated differentiation related to main factors. Also, correlations between factors and protein fraction associated with them were calculated. Mean values of three measurements of considered parameters were used for statistical data analysis.

\section{RESULTS AND DISCUSSION}

The descriptive statistics of technological quality parameters and quantities of protein fractions with different solubility properties (albumins+globulins, gliadins and glutenins), their ratios and shares of glutenin and gliadin fractions from different molecular weight ranges in total protein in examined cultivars determined by RP-HPLC method are provided in Table 1.

Except for gluten index values, which were high for all examined cultivars indicating absence of gluten degradation under influence of unfavorable environmental factors, the ranges of others parameters were broad, indicating wide differentiation of protein composition and quality and thus representing reliable base for intended analysis of interrelations (Table 1 ).

Principal component analysis was conducted for parameters on composition of protein fractions from Table 1. The contribution of identified factors to total variability of sample set indicated that first four PCA factors explain $89.04 \%$ variability of protein composition in investigated wheat cultivars (Fig. 1), with individual contribution of each of first four factors over $10 \%$. The contribution of other factors was lower and based on this remark the further analysis was performed based on analysis of first four PCA factors.

Further step in data analysis was to identify which protein fractions are mainly explaining identified principal components. For this purpose the correlations of protein fractions with identified principal components were calculated (Table 2). The highest correlation coefficient were obtained between total protein content and total content of gluten proteins and both gluten fractions and the first PCA factor, share of $\alpha$-gliadins and LMW glutenins in total protein and GLI/GLU ratio and second PCA factor, content of albumin and globulin and share of $\omega$-gliadins in total protein and third PCA factor and share of $\gamma$-gliadins and HMW glutenins in total protein and the fourth PCA factor. For the protein fractions associated with the same PCA factors, meaning that they demonstrate similar trends, it can be sup-

Table 1. Minimal, maximal and average values and standard deviation of quality parameters of wheat cultivars and content (AU $\mathrm{s} / \mathrm{mg}$ flour) of protein fractions of wheat cultivars used for examination; $G \mathrm{l}=$ gluten index; $F N=$ falling number (s); WA = water absorption (\%); $D D T=$ dough development time (min); $D S=$ degree of softening $(B U) ; E=$ energy $\left(\mathrm{cm}^{2}\right) ; R=$ resistance $(B U)$; $E X T=$ extensibility $(\mathrm{mm}) ; R / E X T=$ ratio resistance/extensibility. $P T=$ total extractible proteins content as summ of $A G, G L I$ and $G L U$ content; $G T=$ total gluten content (sum of GLI and GLU content); $A G$ = content of albumins and globulins; GLI = giladins content; $G L U=$ glutenins content; $G L I / G L U=$ ratio gliadins/glutenins; $\omega / P=$ share of omega gliadins in total protein; $\alpha / P=$ share of alpha gliadins in total protein; $V / P=$ share of gamma gliadins in total protein; $H M W / P=$ share of high molecular weight glutenins in total protein; $L M W / P=$ share of low molecular weight glutenins in total protein

\begin{tabular}{|c|c|c|c|c|}
\hline Parameter & minimal value & maximal value & average value & Standard deviation \\
\hline$\overline{G I}$ & 81 & 100 & 95 & 5.15 \\
\hline$F N$ & 111 & 436 & 299 & 78.87 \\
\hline WA & 56.9 & 68.3 & 62.1 & 2.84 \\
\hline$D D T$ & 1.5 & 10.3 & 3.0 & 1.69 \\
\hline$D S$ & 10 & 125 & 62 & 27.08 \\
\hline$E$ & 42 & 128 & 83 & 27.64 \\
\hline$R$ & 140 & 360 & 235 & 58.05 \\
\hline EXT & 132 & 209 & 169 & 20.17 \\
\hline$R / E X T$ & 0.67 & 2.52 & 1.42 & 0.41 \\
\hline PT & 69.4 & 116.0 & 85.8 & 9.68 \\
\hline$G T$ & 60.5 & 103.1 & 73.5 & 9.51 \\
\hline$A G$ & 8.8 & 20.6 & 12.3 & 2.34 \\
\hline GLI & 21.5 & 42.4 & 28.2 & 4.71 \\
\hline GLU & 36.2 & 60.7 & 45.3 & 5.77 \\
\hline GLI/GLU & 1.23 & 1.95 & 1.63 & 0.21 \\
\hline$\omega / P$ & 2.29 & 7.63 & 3.99 & 1.14 \\
\hline$\alpha / P$ & 19.80 & 32.55 & 28.05 & 2.95 \\
\hline$\gamma / P$ & 16.69 & 27.17 & 20.82 & 2.35 \\
\hline$H M W / P$ & 5.49 & 12.89 & 8.87 & 1.25 \\
\hline$L M W / P$ & 18.5 & 28.86 & 23.86 & 2.41 \\
\hline
\end{tabular}




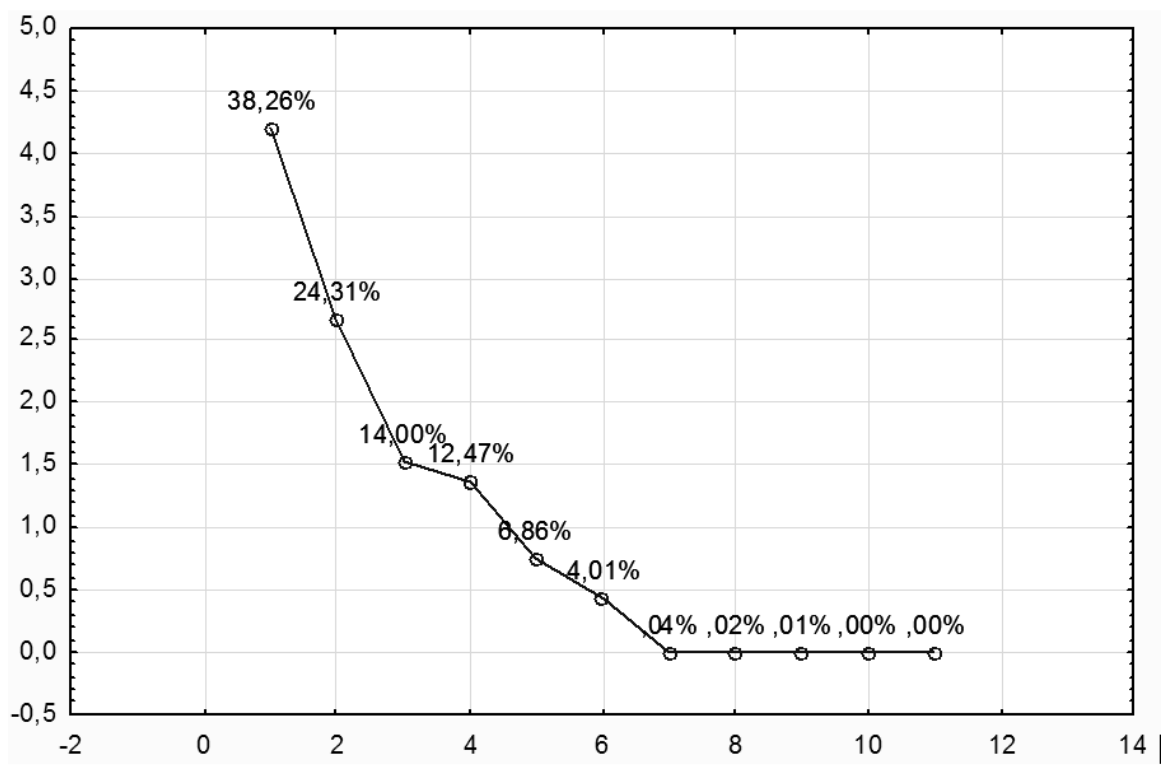

Figure 1. Contribution of PCA factors to the variability among protein fractions of examined cultivars.

posed that joint influence of associated fractions on wheat technological quality will be expressed.

The positions of examined cultivars in factorial plane presenting first vs. second and third vs. fourth PCA factor are presented in Figure 2. The groups of cultivars with extreme positions in factorial plane in respect to observed PCA factors are circled in the graphs, and the ranges of their coordinates in factorial planes with identification of groups of cultivars differentiating based on each of identified PCA factors are provided in Table 3.

Based on visual presentation from Figure 2 examined cultivars were grouped in respect to their differentiation by PCA factors with grouping of four cultivars with extreme negative coordinates in group $A(A 1, A 2$, A3, A4 for first four PCA factors, respectively), with extreme positive coordinates in group $\mathrm{C}(\mathrm{C} 1, \mathrm{C2}, \mathrm{C} 3, \mathrm{C} 4$ for first four PCA factors, respectively) and remaining cultivars in group B (B1, B2, B3, B4 for first four PCA factors, respectively). The lists of cultivars grouped as extremely differentiating for each PCA factor are provided in Table 3.

The significance of differences for all technological quality parameters (Table 1) and for all protein fractions (Table 1) were tested for groups of cultivars (Table 3) obtained in above explained manner. The differences were tested with ANOVA followed by Duncan's test for each observed parameter individually. The parameters for which significant differences were obtained are presented in Table 4.

Differentiation of formed groups based on the first

Table 2. Interrelations of PCA factors with protein fractions; $P T=$ total extractible proteins content as sum of AG, GLI and GLU content; $G T$ = total gluten content (sum of GLI and GLU content); $A G$ = content of albumins and globulins; GLI = giladins content; $G L U=$ glutenins content; $G L I / G L U=$ ratio gliadins/glutenins; $\omega / P=$ share of omega gliadins in total protein; $\alpha / P=$ share of alpha gliadins in total protein; $\gamma / P=$ share of gamma gliadins in total protein; $H M W / P=$ share of high molecular weight glutenins in total protein; $L M W / P=$ share of low molecular weight glutenins in total protein.

\begin{tabular}{|c|c|c|c|c|}
\hline Parameter & PCA factor 1 & PCA factor 2 & PCA factor 3 & PCA factor 4 \\
\hline$P T$ & -0.921 & 0.228 & 0.125 & -0.280 \\
\hline$G T$ & -0.920 & 0.340 & -0.043 & -0.183 \\
\hline$A G$ & -0.070 & -0.436 & 0.694 & -0.414 \\
\hline GLI & -0.713 & 0.654 & -0.045 & -0.245 \\
\hline$G L U$ & -0.987 & -0.113 & -0.032 & -0.068 \\
\hline$G L I / G L U$ & 0.555 & 0.804 & 0.008 & -0.182 \\
\hline$\omega / P$ & 0.111 & 0.473 & 0.726 & 0.039 \\
\hline$\alpha / P$ & -0.134 & 0.720 & -0.320 & 0.461 \\
\hline$\gamma / P$ & 0.436 & 0.210 & -0.398 & -0.606 \\
\hline$H M W / P$ & -0.449 & 0.012 & 0.270 & 0.636 \\
\hline$L M W / P$ & -0.541 & -0.663 & -0.418 & -0.020 \\
\hline
\end{tabular}



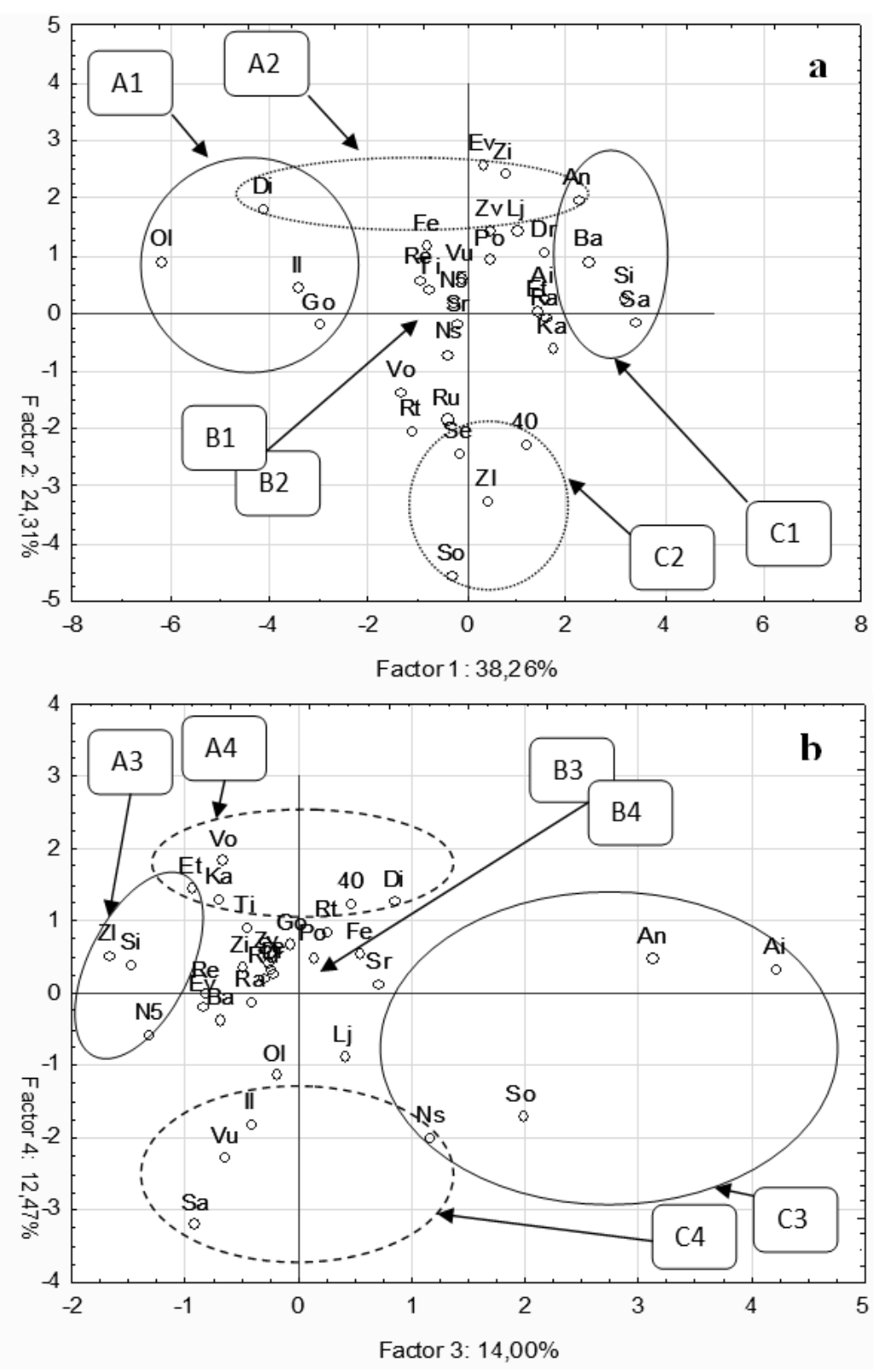

Figure 2. Position of examined cultivars in factorial plane. I-factorial plane in coordinates of PCA factors 1 and 2; II-factorial plane in coordinates of PCA factors 3 and 4 Groups $A 1, A 2, A 3, A 4, B 1, B 2, B 3, B 4, C 1, C 2, C 3, C 4$ defined in table 4 and explained in text; $\mathrm{Sr}=$ Srpanjka; Zi = Žitarka; Di = Divana; $A i=$ Aida; Fe = Felix; ZI = Zlata; II = Ilirija; Ru = Ružica; Sa = Sana; Se = Seka; Rt = Renata; Go = Golubica; So = Soissons; Ol = Olimpija; Vu = Vulkan; Ti = Tihana; Vo = Vojvodina; An = Angelina; $\operatorname{Dr}=$ Dragana; $L j=L j i l j a n a ;$ $N 5=$ NS rana 5; Po = Pobeda; Ba = Bastijana; Ev = Evropa 90; $40=N S$ 40s; Ka = Kantata $; R a=$ Rapsodija; Si $=$ Simonida; Et $=$ Etida; $R e=$ Renesansa; $Z v=$ Zvezdana; Ns = NS3-5299/2.

PCA factor, which is mostly influenced by total protein and gluten content, has confirmed existence of statistically significant differences in total extractable proteins and gluten content, but the difference in total glutenins content was also registered among groups (Table 4, PCA Factor 1). Group A1, characterized with statistically higher protein, gluten and glutenins content was significantly different from other two groups also in respect of higher gliadins content. The cultivars from group A1 are characterized with longer dough development time than cultivars from other two groups and higher energy than cultivars from group C1 with the lowest proteins and gluten content. This observation confirms multiply expressed fact $[1,2,38,39]$ that higher protein content results in stronger dough with longer mixing times and higher energy.

On the other hand cultivars from group C1 (Table 4, PCA Factor 1) with statistically lowest proteins and gluten content were also characterized with significantly lower gluten index, falling number and higher degree of softening than other two groups indicating that the cultivars in this group are probably character- 
Table 3. Groups of cultivars differentiating in respect to observed principal components with ranges of their coordinates in factorial planes

\begin{tabular}{|c|c|c|c|c|}
\hline \multirow{2}{*}{ PCA factor } & \multirow{2}{*}{ Group } & \multirow{2}{*}{ Cultivar } & \multicolumn{2}{|c|}{ Range of coordinates in factorial plane } \\
\hline & & & From & To \\
\hline \multirow[t]{3}{*}{1} & A1 & Divana, Olimpija, Golubica, Ilirija & -6.16 & -3.00 \\
\hline & B1 & Others & -1.34 & 1.73 \\
\hline & C1 & Sana, Angelina, Bastijana, Simonida & 2.25 & 3.41 \\
\hline \multirow[t]{3}{*}{2} & $\mathrm{~A} 2$ & Soissons, Zlata, Seka, NS-40s & -4.54 & -2.26 \\
\hline & B2 & Others & 1.46 & -2.04 \\
\hline & $\mathrm{C} 2$ & Divana, Angelina, Žitarka, Evropa90 & 1.83 & 2.59 \\
\hline \multirow[t]{3}{*}{3} & A3 & Zlata, Simonida, NS rana 5, Etida & -1.68 & -0.95 \\
\hline & B3 & Others & 0.85 & -0.92 \\
\hline & C3 & NS3-5299/2, Soissons, Angelina, Aida & 1.16 & 4.23 \\
\hline \multirow[t]{3}{*}{4} & A4 & Sana, Vulkan, NS3-5299/2, Ilirija & -3.20 & -1.81 \\
\hline & B4 & Others & -1.68 & 1.25 \\
\hline & C4 & Divana, Kantata, Etida, Vojvodina & 1.28 & 1.84 \\
\hline
\end{tabular}

ized with more expressed activity of grain enzyme complex. This observation points out at the conclusion that the cultivars with lower protein content are more susceptible to initiation of enzymatic processes which was not reported in academic literature till now.

Differentiation of formed groups, based on the second PCA factor (Table 4, PCA Factor 2), which is mostly influenced by gliadin/glutenin ratio and the share of low molecular weight glutenins and gliadins ( $\alpha$-gliadins) in total protein, leads to several conclusions. Namely, the C2 group of varieities with statistically higher content of albumins and globulins,

Table 4. Differentiation of protein fractions' content and technological quality parameters among groups of cultivars differentiated by PCA factors; PT = total extractible proteins content as summ of AG, GLI and GLU content; GT = total gluten content (sum of GLI and $G L U$ content); $G L U$ = glutenins content; $G L I=$ giladins content; $G I=$ gluten index; $F N=$ faling number value (sec); $D D T=$ dough development time (min); $D S=$ degree of softening $(B U) ; E=$ energy $\left(\mathrm{cm}^{2}\right) ; A G=$ content of albumins and globulins; $G L I / G L U=$ ratio gliadins/glutenins; $\alpha / P=$ share of alpha gliadins in total protein; $\omega / P=$ share of omega gliadins in total protein; $L M W / P=$ share of low molecular weight glutenins in total protein; $W A=$ water absorption (\%); $R=$ resistance (BU); $R / E X T=$ ratio resistance/extensibility; EXT = extensibility $(\mathrm{mm}) ; \mathrm{V} / \mathrm{P}=$ share of gamma gliadins in total protein; $\mathrm{HMW} / \mathrm{P}=$ share of high molecular weight glutenins in total protein; means with the same letter do not differ significantly

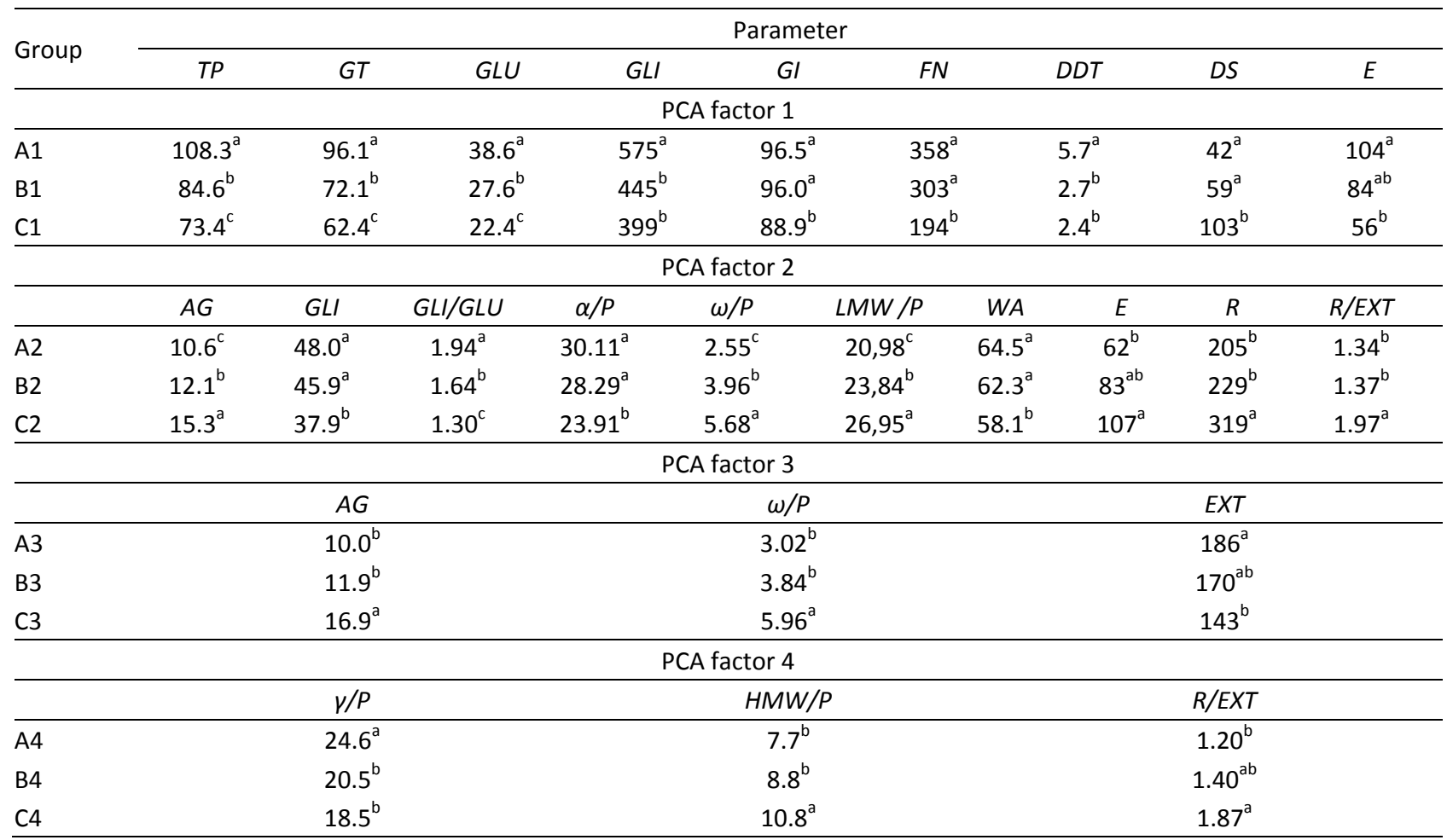


$\omega$-gliadin and low molecular weight glutenin share in total protein accompanied with statistically lower gliadin content, gliadin/glutenin ratio and $\alpha$-gliadin share in total protein, was characterized with statistically lower water absorption and statistically higher energy resulting from higher resistance and higher resistance to extensibility ratio. This remark provides understanding of protein composition that causes low water absorption and high extensigraph resistance as undesirable characteristics of wheat cultivars. On the other hand, the cultivars from group A2 with lower content of albumins and globulins and lower shares of $\omega$-gliadins and low molecular weight glutenins in total protein, did not reveal differentiation in technological quality parameters from group B2.

Analysis of differentiation of protein fractions composition and technological quality parameters among groups of differentiated cultivars, based on the third PCA factor (Table 4, PCA Factor 3), which is mostly influenced by albumins and globulins content and share of $\omega$-gliadins in total proteins, reveals that the cultivars from group C3 with significantly higher albumins and globulins content and significantly higher share of $\omega$-gliadins in total proteins express significantly lower extensigraph extensibility in respect to cultivars from group $A 3$, regarding mentioned properties that have opposite performance. This observation points out at possible role of increased shares of mentioned proteins' fractions in shortening of dough extensibility.

The analysis of significance of differences among the mean values of protein fractions and technological parameters values for cultivars from groups, formed on the basis of fourth PCA factor (Table 4, PCA Factor 4), which is mostly influenced by the share of $\gamma$-gliadins and high molecular weight glutenins in total proteins, indicates that higher share of $\gamma$-gliadins in total proteins leads to lower ratio of extensigraph resistance and extensibility, while higher molecular weight of glutenins' share in total proteins causes the opposite dough behavior.

Explained observation obtained by multivariate approach to the consideration of influence of wheat protein fractions and their proportion on dough rheological properties partly confirms already determined influence of individual wheat protein fractions on rheological properties of dough [40], pointing out also the dependencies of rheological properties on interrelations of protein fractions and their overall proportion have to be reconsidered and more thoroughly analyzed in future investigations.

\section{CONCLUSION}

Applied combination of multivariate and univariate statistical techniques points out at the following inter- relations among protein fractions and technological quality parameters of investigated wheat cultivars:

- Cultivars with low total extractible proteins and total gluten content tend to be more susceptible to enzymatic processes in dough.

- Cultivars characterized with higher content of albumins and globulins and low molecular weight glutenin share in total protein accompanied with lower gliadin content, gliadin/glutenin ratio and $\alpha$ - gliadin share, are characterized with low water absorption, high energy and high resistance to extensibility ratio.

- Combination of high albumins and globulins content and high share of $\omega$-gliadins in total proteins results in lower extensigraph extensibility.

- High HMW-GS share in total proteins results in higher extensigraph resistance/extensibility ratio, while high $\gamma$-gliadins share in total proteins has the opposite effect.

Obtained results point out at the possibility of successful application of combination of multivariate and differential statistics for investigation of interrelations of wheat composition components and its technological quality, providing useful approach for innovative analysis in corresponding research areas.

\section{Acknowledgements}

This work was supported by the Ministry of Education, Science and Technological Development of the Republic of Serbia within the Project of technological development No. TR 31007 (2011-2015) and bilateral cooperation between Serbia and Croatia - Genetic polymorphism of gluten proteins and its relationship to bread-making quality of wheat (Triticum aestivum L.).

\section{REFERENCES}

[1] D. Ćurić, D. Karlović, D. Tušak, B. Petrović, J. Đugum, Gluten as a standard of wheat flour quality, Food Technol. Biotechnol. 39 (2001) 353-361.

[2] F.E. Dowell, E.B. Maghirang, R.O. Pierce, G.L. Lookhart, S.R. Bean, F. Xie, M.S. Caley, J.D. Wilson, B.W. Seabourn, M.S. Ram, S.H. Park, O.K. Chung, Relationship of bread quality to kernel, flour and dough properties, Cereal Chem. 85 (2008) 82-91.

[3] C. Luo, W.B. Griffin, G. Branlard, D.L. McNeil, Comparison of low- and high molecular-weight wheat glutenin allele effects on flour quality, Theor. Appl. Genet. 102 (2001) 1088-1098.

[4] M.R. Pirozi, B. Margiotta, D. Lafiandra, F. MacRitchie, Composition of polymeric proteins and bread-making quality of wheat lines with allelic HMW-GS differing in number of cysteines, J. Cereal Sci. 48 (2008) 117-122.

[5] M. Rakszegi, G. Pastori, H.D. Jones, F. Békés, B. Butow, L. Láng, Z. Bedő, P.R. Shewry, Technological quality of field grown transgenic lines of commercial wheat cultivars expressing the $1 \mathrm{Ax} 1 \mathrm{HMW}$ glutenin subunit gene, J. Cereal Sci. 47 (2008) 310-321. 
[6] A.Mohamed, P. Rayas-Duarte, S.H. Gordon, J. Xu, Estimation of HRW wheat heat damage by DSC, capillary zone electrophoresis, photoacoustic spectroscopy and rheometry, Food Chem. 87 (2004) 195-203.

[7] D. Živančev, A. Torbica, J. Mastilović, N. Hristov, J. Tomić, D. Stanić, Investigation of relations between HMW glutenin composition and rheological properties of contemporary wheat varieties, Proceedings of 6th Central European Congress on Food, Novi Sad, Serbia, 2012, pp. 419-423.

[8] D. Horvat, Z. Jurković, G. Drezner, G. Šimić, D. Novoselović, K. Dvojković, Influence of gluten proteins on technological properties of Croatian wheat cultivars, Cereal Res. Comm. 34 (2006) 1177-1184.

[9] D. Horvat, Ž. Kurtanjek, G. Drezner, G. Šimić, D. Magdić, Effect of HMM glutenin subunits on wheat quality attributes, Food Technol. Biotechnol. 47 (2009) 253-259.

[10] J.S. Wang, M.M. Zhao, Q.Z. Zhao, Correlation of glutenin macropolymer with viscoelastic properties during dough mixing, J. Cereal Sci. 45 (2007) 128-133.

[11] P. Zhang, Z. He, D. Chen, Y. Zhang, O.R. Larroque, X. Xia, Contribution of common wheat protein fractions to dough properties and quality of northern-style Chinese steamed bread, J. Cereal Sci. 46 (2007) 1-10.

[12] B. Varga, Z. Svečnjak, Z. Jurković, J. Kovačević, Ž. Jukić, Wheat grain and flour quality as affected by cropping intensity, Food Technol. Biotechnol. 41 (2003) 321-329.

[13] A.Torbica, M. Antov, J. Mastilović, D. Knežević, The influence of changes in gluten complex structure on technological quality of wheat (Triticum aestivum L.), Food. Res. Int. 40 (2007) 1038-1045.

[14] F. MacRitchie, Evaluation of contributions from wheat protein fractions to dough mixing and breadmaking, J. Cereal Sci. 6 (1987) 259-268.

[15] P.I. Payne, L.M. Holt, E.A. Jackson, C.N. Law, Wheat storage proteins. Their genetics and their potential for manipulation by plant breeding, Philos. T. Roy. Soc., B 304 (1984) 359-371.

[16] N.A.C. Bunce, R.P. White, P.R. Shewry, Variation in Estimates of Molecular Weights of Cereal Prolamins by SDS-PAGE, J. Cereal Sci. 3 (1985) 131-142.

[17] P.W. Gras, R.S. Anderssen, M. Keentok, F. Békés, R. Appels, Gluten protein functionality in wheat flour processing: a review, Aust. J. Agric. Res. 52 (2001) 1311$-1323$.

[18] P.I. Payne, M.A. Nightingale, A.F. Krattiger, L.M. Holt, The relationship between HMW glutenin subunit composition and the bread-making quality of British-grown wheat varieties, J. Sci. Food. Agr. 40 (1987) 51-65.

[19] D. Lafiandra, R. D'Ovidio, E. Porceddu, B. Margiotta, G. Colaprico, New data supporting high $\mathrm{Mr}$ glutenin subunit 5 as the determinant of quality differences among the pairs $5+10$ vs. $2+12$, J. Cereal Sci. 18 (1993) 197-205 .

[20] J.H. Woychick, J.A. Boundy, R.J. Dimler, Starch gel electrophoresis of wheat gluten proteins with concentrated urea, Arch. Biochem. Biophys. 94 (1961) 477-482 .
[21] N.H. Thomson, M.J. Miles, Y. Popineau, J. Harries, P. Shewry, A.S. Tatham, Small angle X-ray scattering of wheat seed-storage proteins: $\alpha-, \gamma$ - and $\omega$-gliadins and the high molecular weight (HMW) subunits of glutenin, Biochim. Bioophys. Acta- Protein Proteomics 1430 (1999) 359-366.

[22] E.V. Metakovsky, Gliadin allele identification in common wheat II. Catalogue of Gliadin alleles in common wheat, J. Genet. Breeding 45 (1991) 325-344.

[23] G. Branlard, I. Felix, Part of HMW glutenin subunits and omega gliadin allelic variants in the explanation of the quality parameters, in Proceedings of the Int. MeetingWheat Kernel Proteins: molecular and functional aspects, S. Martin al Cimino, Viterbo, Italy, 1994, pp. 249-251.

[24] A. Wang, L. Gao, X. Li, Y. Zhang, Z. He, X. Xia, Y. Zhang, Y. Yan, Characterization of two $1 \mathrm{D}$-encoded $\omega$-gliadin subunits closely related to dough strength and pan bread-making quality in common wheat (Triticum aestivum L.), J. Cereal Sci. 47 (2008) 528-535.

[25] S. Gobaa, E. Bancel, G. Branlard, G. Kleijer, P. Stamp, Proteomic analysis of wheat recombinant inbred lines: Variations in prolamin and dough rheology, J. Cereal Sci. 48 (2008) 610-619.

[26] J. Gil-Humanes, F. Pistón, C.M. Rosell, F. Barro, Significant down-regulation of $y$-gliadins has minor effect on gluten and starch properties of bread wheat, J. Cereal Sci. 56 (2012) 164-170.

[27] G. Cleemput, M. Hessing, M. Van Oort, M. Deconynck, J.A. Delcour, Purification and characterization of a B-D-xylosidase and endo-xylanase from wheat flour, Plant Physiol. 113 (1997) 377-386.

[28] C.E. Stauffer, in J.E. Kruger, D. Linebak, C.E Stauffer (Eds.), Enzymes and Their Role in Cereal Technology, American Association of Cereal Chemistry, Paul, MN, 1987, pp. 201-237.

[29] D. Horvat, G. Šimić, G. Drezner, K. Dvojković, The influence of albumins and globulins on bread-making quality of wheat (Triticum aestivum L.), Agron. Glas. 69 (2007) 135-145.

[30] W.S. Vervabeke, J.A. Delcour, Wheat protein composition and properties of wheat glutenin in relation to breadmaking functionality, CRC Cr. Rev. Food Sci. 42 (2002) 179-208.

[31] Ž. Kurtanjek, D. Horvat, D. Magdić, G. Drezner, Factor analysis and modelling for rapid quality assessment of Croatian wheat cultivars with different gluten characteristics, Food Technol. Biotechnol. 46 (2008) 270-277.

[32] Determination of the "Falling Number" according to Hagberg-Perten as a measure of the degree of alphaamylase activity in grain and flour, ICC Standard No. 107/1, International Association for Cereal Science and Technology, Vienna, Austria, 1995.

[33] Determination of Wet Gluten Quantity and Quality (Gluten Index ac. to Perten) of Whole Wheat Meal and Wheat Flour (Triticum aestivum), ICC Standard No. 155, International Association for Cereal Science and Technology, Vienna, Austria, 1994. 
[34] Method for Using the Brabender Farinograph, ICC Standard No. 115/1, International Association for Cereal Science and Technology, Vienna, Austria, 1992.

[35] Method for Using the Brabender Extensograph, ICC Standard No. 114/1, International Association for Cereal Science and Technology Vienna, Austria, 1992.

[36] H. Wieser, S. Antes, W. Seilmeier, Quantitative determination of gluten protein types in wheat flour by reversed-phase high-performance liquid chromatography, Cereal Chem. 75 (1998) 644-650.

[37] statistica (Data Analysis Software System), version 10. StatSoft, Inc, Tulsa, OK, 2011 (www.statsoft.com).
[38] W. Bushuk, K.G. Briggs, L.H. Shebeski, Protein quantity and quality as factors in the evaluation of bread wheats, Can. J. Plant. Sci. 49 (1969) 113-122.

[39] S. Uthayakumaran, O.M. Lukow, Functional and multiple end-use characterisation of Canadian wheat using a reconstituted dough system, J. Sci. Food Agric. 83 (2003) 889-898.

[40] H. Goesaert, K. Brijs, W.S. Veraverbeke, C.M. Courtin, K. Gebruers, J.A. Delcour, Wheat flour constituents: how they impact bread quality, and how to impact their functionality, Trends Food Sci. Tech. 16 (2005) 12-30.

\section{IZVOD}

\section{ANALIZA MEĐUZAVISNOSTI SASTVA FRAKCIJA PROTEINA I TEHNOLOŠKOG KVALITETA PŠENICE PRIMENOM KOMBINACIJE MULTIVARIJANTNE I UNIVARIJANTNE STATISTIKE}

Jasna Mastilović ${ }^{1}$, Daniela Horvat ${ }^{2}$, Dragan Živančev ${ }^{1}$, Aleksandra Torbica ${ }^{1}$, Žarko Kevrešan ${ }^{1}$, Nevena Đukić ${ }^{3}$, Damir Magdić, Gordana Šimić ${ }^{2}$

${ }^{1}$ Univerzitet u Novom Sadu, Institut za prehrambene tehnologije, Bulevar cara Lazara 1, 21000 Novi Sad, Srbija

${ }^{2}$ Agricultural Institute Osijek, Južno predgrađe 17, 31000 Osijek, Croatia

${ }^{3}$ Univerzitet u Kragujevcu, Prirodno-matematički fakultet, Radoja Domanovića 12, 34000 Kragujevac, Srbija

${ }^{4}$ University J.J. Strossmayer, Faculty of Food Technology Osijek, Franje Kuhača 18, 31000 Osijek, Croatia

(Naučni rad)

Podaci o odnosu frakcija proteina pšenice dobijeni primenom RP-HPLC i parametri tehnološkog kvaliteta 32 sorte pšenice uzgajane u Srbiji i Hrvatskoj su korišćeni za izučavanje međuzavisnosti frakcija proteina pšenice različite rastvorljivosti i molekulskih masa primenom multivarijantne (PCA) analize. Utvrđeni trendovi su upotrebljeni kao osnova za ispitivanje diferenciranja tehnološkog kvaliteta među sortama okarakterisanim različitim kombinacijma proteinskih frakcija uz primenu univarijantne statistike (analiza varijanse praćena Dankanovim testom značajnosti razlika) sa ciljem da se dobije informacija o međuzavisnosti između sastava frakcija proteina sorti pšenice i njhovog tehnološkog kvaliteta. Analiza zasnovana na prva četiri PCA faktora (89.04\% varijabilnosti) ukazuje na zavisnosti između: 1) visokog sadržaja albumina i globulina, niskog sadržaja glijadina i odnosa glijadina i glutnina, visokog sadržaja $\omega$-glijadina, niskomolekularnih glutenina i niskog udela $\alpha$-glijadina u ukupnim proteinima sa niskom moći upijanja vode, visokom energijom i visokim odnosnim brojem, 2) visokog sadržaja albumina i globulina i visokog udela $\omega$-glijadina u ukupnim proteinima i niske rastegljivosti na ekstenzogramu, 3) visokog udela visokomolekularnih glutenina u ukupnim proteinima i visokog odnosnog broja i 4) visokog udela $\gamma$-glijadina u ukupnim proteinima i niskog odnosnog broja.
Ključne reči: Pšenica • Genotip • Tehnološke osobine • Albumini i globulini • Gluten • RP-HPLC 